\title{
Sulfide mineralization and fluid inclusion characteristics of active ultramafic- and basalt-hosted hydrothermal vents located along the Arctic Mid-Ocean Ridges (AMOR)
}

\author{
S. Strmic PalinKas ${ }^{1,2, *}$, R.B. PEDERSEN ${ }^{2}$, AND F. \\ SAHLSTRÖM $^{1}$
}

${ }^{1}$ UiT The Arctic University of Norway, Department of Geosciences, Tromsø, Norway (*correspondence: sabina.s.palinkas@uit.no)

${ }^{2}$ University of Bergen, Department of Earth Science, K.G. Jebsen Centre for Deep Sea Research, Bergen, Norway

The AMOR, an oceanic ridge system located north of the Arctic circle $\left(66^{\circ} \mathrm{N}\right)$, consists of several slow and ultraslow spreading ridges. This study is focused on the sulfide mineralization hosted by basalts and ultramafic rocks along the ultraslow Mohns ridge segment of the AMOR.

The Fåvne vent field $\left(72.8^{\circ} \mathrm{N}, 4.2^{\circ} \mathrm{E}, \sim 3000 \mathrm{~m}\right.$ depth) is hosted by ultramafic rocks. The sulfide mineralization, predominantly composed of isocubanite, pyrrhotite and chalcopyrite, is accompanied by various amounts of Fe-oxyhydroxides and anhydrite. The bulk composition of analyzed samples shows high concentrations of $\mathrm{Cu}$ and $\mathrm{Co}$ (up to 9.15 wt.\% and $9780 \mathrm{ppm}$, respectively) and low concentrations of other metals and metalloids, including $\mathrm{Zn}, \mathrm{Pb}$ and $\mathrm{Ag}$. The $\mathrm{Au}$ content varies between 0.03 and $1.6 \mathrm{ppm}$. The ongoing LA-ICP-MS study of sulfide minerals has revealed that Co is predominantly sitting in the crystal lattices of isocubanite and pyrrhotite. Anhydrite from the Fåvne vent field predominantly hosts two-phase fluid inclusion assemblages. Their petrographic characteristics and microthermometric data reflect a mixing trend of hot saline hydrothermal fluids with cold seawater.

The Loki's Castle vent field $\left(73.6^{\circ} \mathrm{N}, 8.2^{\circ} \mathrm{E}, \sim 2400 \mathrm{~m}\right.$ depth) is hosted by basalts. The major sulfide minerals are pyrite and marcasite. Isocubanite, chalcopyrite, pyrrhotite, sphalerite and galena are common but their amounts significantly vary between analyzed samples. Amorphous silica, anhydrite and barite are the major gangue minerals. The bulk $\mathrm{Cu}, \mathrm{Zn}$ and $\mathrm{Pb}$ content varies between $300 \mathrm{ppm}$ and 2.4 wt.\%, 140 ppm and 9.15 wt.\%, and 45 ppm and 2.17 wt.\%, respectively. The mineralization is poor in Co but enriched in $\mathrm{Ag}, \mathrm{Au}, \mathrm{Sb}, \mathrm{As}, \mathrm{Se}, \mathrm{Hg}$ and $\mathrm{Tl}$. Amorphous silica from the Loki's Castle hosts two-phase fluid inclusion assemblages that preserve characteristics of hydrothermal ore-bearing fluids. In contrast, fluid inclusions entrapped in barite show composition close to seawater. 